\title{
Aerial Photography Used for Spatial Pattern Analysis of Late Blight Infection in Irrigated Potato Circles
}

\author{
Dennis A. Johnson, J. Richard Alldredge, Philip B. Hamm, and Bruce E. Frazier
}

First author: Department of Plant Pathology, Washington State University, P.O. Box 646430, Pullman 99164; second author: Program in Statistics, Washington State University; third author: Department of Botany and Plant Pathology, Hermiston Agricultural Research and Extension Center, Oregon State University, P.O. Box 105, Hermiston, OR; and fourth author: Crop and Soil Sciences Department, Washington State University.

Accepted for publication 17 February 2003.

\begin{abstract}
Johnson, D. A., Alldredge, J. R., Hamm, P. B., and Frazier, B. E. 2003. Aerial photography used for spatial pattern analysis of late blight infection in irrigated potato circles. Phytopathology 93:805-812.

Spatial and temporal dynamics of late blight were investigated from color, infrared aerial photographs of five commercial potato fields in the Columbia Basin during epidemics in 1993, 1995, and 1998. Aerial photographs were taken one to four times at 6- to 21-day intervals. Photographs were scanned and pixels, representing approximately $1 \mathrm{~m}^{2}$ in the field, were used in the analysis. Late blight-infected plants were aggregated as indicated by runs analysis. Significant z-tests were computed for four directions during each sampling date in each of the five fields. Absolute $z$-values for runs analysis increased, indicating increasing

aggregation in the four directions, as disease incidence increased in the early and midphases of the epidemics in each field. Variograms indicated the existence of autocorrelation among infected plants in four directions; the range of influence increased as disease incidence increased except at the highest levels of disease. Late blight was observed to spread in fields as foci. Late blight foci enlarged in size, produced distinct daughter foci, and coalesced. A field where initial inoculum likely originated from infected seed tubers exhibited less initial aggregation than the other fields, perhaps due to a different source of primary inoculum. Aerial photography coupled with spatial analyses of late blight-infected plants was an effective technique to quantitatively assess disease patterns in relatively large fields and was useful in quantifying an intensification of aggregation during the epidemic process on a large scale.
\end{abstract}

Severe epidemics of late blight, caused by Phytophthora infestans (Mont.) de Bary, have occurred in irrigated potato circles of the Columbia Basin in Oregon and Washington since 1991 $(18,19)$. Late blight did not occur regularly in this semiarid environment before 1990 (19). Several factors have contributed to the recent epidemics of late blight in the region, including the appearance of a population of $P$. infestans that is insensitive to the fungicide metalaxyl, highly aggressive on potato, and efficiently transmitted from seed tubers to emerging sprouts (26-29). In addition, above average precipitation, especially early in the growing season (19), and expanded production of early season potato cultivars that are extremely susceptible to $P$. infestans (15) likely have contributed to these epidemics. Cost of managing the epidemic in the Columbia Basin approached \$30 million in 1995 and was \$22.3 million in 1998 (20,21). Average cost per acre of fungicides and applications on late-season potatoes in 1998 was $\$ 128$ in the north basin and \$191 in the south basin of Washington (20).

Primary inoculum for late blight epidemics may originate from a number of sources. $P$. infestans can persist as mycelium in infected tubers from season to season (37). Sources of overwintering inoculum can be seed tubers, tubers giving rise to volunteer plants, and refuse tubers and tuber pieces (37). Oospores in soil may also be a source of early spring inoculum (9). Sexual reproduction of $P$. infestans has likely occurred in the Columbia Basin $(11,27)$, but oospores have not been observed nor has the expected increase in genotype diversity associated with sexual reproduction occurred.

Corresponding author: D. A. Johnson; E-mail address: dajohn@wsu.edu

Publication no. P-2003-0505-01R

(c) 2003 The American Phytopathological Society
Late blight spreads rapidly on susceptible potato cultivars when favored by cool, wet conditions. Spatial variation is a property of natural populations and is often dynamic, changing as the population increases or decreases in number $(7,16,17,33)$. Patterns of diseased plants and pathogens are often aggregated $(7,8,16,17$, $35,36)$ and the degree of aggregation and amount of change over time is a property of natural populations in particular environments $(39,42)$. The spatial pattern of late blight within a circle is likely to change as disease spreads. The degree of disease aggregation is expected to decrease as focal expansion occurs (34); however, patterns of late blight over time have not been spatially quantified. A large crop area would be needed to quantify spatial patterns of late blight in a field over time. Assessing disease over a large crop area is virtually impossible from the ground (2).

Aerial photography has been useful to detect late blight foci, determine late blight incidence, and monitor plant stress caused by various factors over large crop areas $(2-6,24,38)$. However, areas of stressed plants detected from the air usually need to be observed firsthand to identify or confirm the specific cause of plant stress (32). A loss in near-infrared reflectance in a plant canopy can be related to the extent of foliage damage due to late blight or other diseases $(10,24,25,38)$. Late blight causes potato leaves to turn black in color and cells to shrivel and dry. The normal (healthy) potato leaf color as seen on an infrared photograph is supported by green leaves and turgid cells, and will appear red in the photograph. The blackening of leaves and shrinkage of the canopy causes a reduction in green, red, and infrared reflectance. Exposure of bare soil also results from shrinkage in the canopy. Thus, as the disease progresses and the canopy decreases, more wet, irrigated soil is exposed to the camera and the disease is expressed as a darkening of the image. Areas of the field with late blight appear tan to black in the infrared photograph. Dry soil with no vegetation appears white to bluish. 
Aerial photographs were taken in commercial potato circles to aid in disease management decisions in the Columbia Basin during recent late blight epidemics. Aerial photography allows the possibility of spatially analyzing relatively large areas within a field, and the opportunity became available to evaluate aerial photography coupled with quantitative spatial analyses in studying patterns of disease over time, and to study spatial patterns of late blight in commercial potato circles under current management practices during the course of severe epidemics. Such information may increase understanding of the spread of late blight in large commercial fields and help in developing disease management strategies. The objectives of this study were to use aerial photography as a technique to quantitatively analyze spatial patterns of late blight-infected foliage and to statistically describe spatial patterns of late blight epidemics in relatively large commercial fields under current disease management practices.

\section{MATERIALS AND METHODS}

Four potato fields near Hermiston, OR, and one north of Pasco, WA, were chosen for the study. The five fields ranged from 11 to 51 ha in size and were planted with cvs. Norkotah Russet, Shepody, or Russet Burbank; Norkotah Russet and Shepody are more susceptible to P. infestans than Russet Burbank (15). All fields were irrigated by center pivot irrigation systems and were planted with certified seed tubers from middle March through April 1993, 1995, or 1998. None to nine fungicide applications were made on each field (Table 1). Rates of fungicides applied were those recommended by the manufacturer's label.

Field I was planted to 'Norkotah Russet' potato in a fine sand soil near Hermiston, OR, in 1993 and was approximately 51 ha in size. An aerial photograph was taken on 2 August 1993. A record of when late blight was first observed on the ground in this field was not noted, but late blight was first observed in a nearby field on 19 July 1993. Only half of the field was analyzed statistically because foliage in half of the circle was dry while the remaining half was wet due to a concurrent irrigation application

TABLE 1. Fungicides applied to five potato fields in the Columbia Basin for late blight management

\begin{tabular}{|c|c|c|}
\hline Field & Date & Fungicide ${ }^{\mathrm{a}}$ \\
\hline I & $\begin{array}{l}29 \text { June } 1993 \\
16 \text { July } 1993 \\
\text { 22 July } 1993 \\
\text { 27 July } 1993 \\
\text { 1 August } 1993\end{array}$ & $\begin{array}{l}\text { Copper hydroxide* } \\
\text { Copper hydroxide* } \\
\text { Metalaxyl + mancozeb* } \\
\text { Chlorothalonil* } \\
\text { Copper hydroxide* }\end{array}$ \\
\hline II & $\begin{array}{l}\text { 21 June } 1995 \\
\text { 1 July } 1995 \\
\text { 10 July } 1995 \\
\text { 17 July } 1995\end{array}$ & $\begin{array}{l}\text { Chlorothalonil* } \\
\text { Chlorothalonil }{ }^{* *} \\
\text { Triphenyltin hydroxide** } \\
\text { Dimethomorph + mancozeb* }\end{array}$ \\
\hline III & $\begin{array}{l}18 \text { June } 1995 \\
1 \text { July } 1995 \\
10 \text { July } 1995 \\
16 \text { July } 1995 \\
19 \text { July } 1995 \\
\text { 21 July } 1995 \\
1 \text { August } 1995\end{array}$ & $\begin{array}{l}\text { Chlorothalonil* } \\
\text { Chlorothalonil** } \\
\text { Triphenyltin hydroxide** } \\
\text { Dimethomorph + mancozeb* } \\
\text { Cymoxanil + mancozeb** } \\
\text { Cymoxanil + mancozeb* } \\
\text { Propamocarb hydrochloride + chlorothalonil* }\end{array}$ \\
\hline IV & - & No fungicides applied \\
\hline V & $\begin{array}{l}\text { 22 June } 1998 \\
\text { 25 June } 1998 \\
\text { 30 June } 1998 \\
\text { 1 July } 1998 \\
\text { 2 July } 1998 \\
\text { 9 July } 1998 \\
\text { 14 July } 1998 \\
\text { 20 July } 1998 \\
\text { 27 July } 1998\end{array}$ & $\begin{array}{l}\text { Cymoxanil + chlorothalonil** } \\
\text { Cymoxanil + chlorothalonil* } \\
\text { Dimethomorph + mancozeb* } \\
\text { Cymoxanil + chlorothalonil* } \\
\text { Dimethomorph + mancozeb*** } \\
\text { Dimethomorph + mancozeb*** } \\
\text { Mancozeb + triphenyltin hydroxide* } \\
\text { Chlorothalonil + triphenyltin hydroxide* } \\
\text { Dimethomorph + mancozeb* }\end{array}$ \\
\hline
\end{tabular}

a $*$ Indicates application by air, ** indicates application through center pivot system, and $* * *$ indicates application by ground sprayer. at time of photography. This gave a differential light reflection in the two halves.

Field II was planted to 'Shepody' potato in a sandy loam soil near Hermiston in 1995. The field was a half circle approximately 12 ha in size. Aerial photographs were taken on 3, 17, and 24 July 1995. Field III was planted to 'Russet Burbank' potato in a sandy loam soil near Hermiston in 1995. The field was a complete circle 11 ha in size. Aerial photographs were taken on 17 and 24 July and 8 August. Late blight was first observed in the Hermiston area on 6 June 1995.

Field IV was planted to cv. Shepody potato in a loamy sand soil north of Pasco, WA in 1995. The field was a complete circle 51 ha in size. Late blight was first observed in the area after 14 June. Aerial photographs were taken 29 June and 6 July. Fungicides were not applied to the field.

Field V was planted to cv. Russet Norkotah potato in a loamy fine sand soil near Hermiston on 25 April 1998. The field was a complete circle 51 ha in size. In 1998, late blight was first observed in the Hermiston area in this field on 22 June. Late blight was not found in other fields in the Hermiston area in the next 14 days. The first confirmed occurrence of late blight in the Columbia Basin in 1998 was in a field approximately $56 \mathrm{~km}$ to the north near Pasco, WA on 15 June. The prevailing wind blows from the southwest. Two days later the disease was found in three additional fields within $300 \mathrm{~m}$ to $6 \mathrm{~km}$ of the field near Pasco. Additional fields with late blight were not found in the Pasco area for another 12 days. These fields with late blight near Pasco and Hermiston contained cv. Norkotah Russet and seed tubers had originated from the same farm from another state. Late blight was reported to have been present in the seed production fields in 1997. Aerial photographs were taken on 23 June, 29 June, 6 July, and 27 July 1998.

Aerial photography was from fixed wing aircraft using Kodak 2443 color infrared, 70-mm film (Kodak, Rochester, NY). An 80-mm lens was used for fields I to III and V and a 45-mm lens was used for field IV. Photography Plus, Inc. (Umatilla, OR) took photographs for fields I to III and V, and Professional Ag Services (Pasco, WA) took photographs for field IV. The occurrence of late blight was confirmed on the ground in each field.

Photographs were scanned with a VISTA SCAN 32 (UMAX Technologies, Inc., Fremont, CA) in true color at 300 dpi. They were exported in TIF format to Adobe Photoshop 3.0 (Adobe Systems, Inc., Seattle, WA) and Idrisi (Idrisi Production, Worcester, MA) for analysis. The TIF files were separated into red, green, and blue data layers using Adobe. Idrisi software was used to search for clusters of similar data that could be related to levels of disease in the fields. Unsupervised clustering was used to create 10 classes for each field. Idrisi software was used to sample the images to create manageable file sizes and realistic pixel size (picture element [32]) on the ground. Thus, output pixels represented approximately $1 \mathrm{~m}^{2}$ (3.6 plants per $\mathrm{m}^{2}$ ) in the field. The position of each pixel with respect to an origin defined within each field and the cluster number, representing level of disease, were written for statistical processing. An indicator transformation was used to classify each pixel as diseased or nondiseased (13). This transformation allowed comparison of disease occurrence patterns between fields with differing levels of disease assigned to the 10 classes for each field. A rectangular section within each field was then used for statistical analyses.

Runs analysis $(12,23,39)$ and indicator variograms (22) were used to examine the spatial association of late blight between nearby pixels and for pixels more separated in space. Each analysis was done in four directions (north, northeast, east, and southeast). Space for roads going into the pivot center, wheel tracks in the field from the pivot, and the pivot were treated as missing values.

A runs analysis (12) was used to examine aggregation of disease pixels compared with the mixing of diseased and healthy 
pixels expected for randomly distributed occurrence of disease. A run is defined as a succession of one or more healthy or diseased pixels that are followed and preceded by a pixel of the other disease status or no pixel at all. There would be few runs if there were aggregation of diseased or healthy pixels and a large number of runs for a random mixing of diseased and healthy pixels. Under the null hypothesis of randomness, the expected value and standard deviation of the total number of runs in the $i$ th row may be obtained from equations presented by Madden et al. (23).

The ordinary runs analysis (12) was modified to allow for multiple rows of observations and for missing values (16). A row was defined as a series of adjacent pixels in the specified direction terminated either by the boundary of the study section of the field or by a missing pixel. A test statistic with an asymptotic normal distribution will have a large negative number if there is clustering; so the test for nonrandomness is left-tailed. The runs test was performed in the direction of each axis of a rectangular section within the field and in two diagonal directions.

Spatial autocorrelation was examined in four directions with indicator variograms. These variograms are related to correlograms (1) and display the degree of correlation of disease from spatially contiguous pixels at successively larger distances. The minimum lag distance used to plot variograms was approximately $1 \mathrm{~m}$.

The experimental variograms were estimated using SAS Proc Variogram (version 8; SAS Institute, Cary, NC). Exponential and spherical models were fit to all data using weighted least squares in SAS Proc Nlin (version 8). The model with the smallest residual mean square was reported. If only one model converged, that model was reported. In a few cases neither model converged so a linear model was fit using SAS Proc Reg (version 8). The estimated parameters for the exponential and spherical models are the nugget, sill-nugget, and range of influence. The distance over which the variogram continues to increase indicates the range of influence of disease pixels on nearby pixels. Disease status is considered to be spatially correlated for pixels separated by distances less than the range. The nugget is related to measurement error and/or spatial sources of variation at distances smaller than the shortest lag distances. The horizontal part of the curve, the sill, is at a value around which the variogram becomes stable, hence the sill-nugget is the contribution of non-nugget structures to the total variance. Because the exponential model reaches its sill asymptotically, a practical range is defined as the distance at which the model value is at $95 \%$ of the sill (13). The exponential and spherical variogram models were chosen because they appeared to provide an adequate representation of the shape of most of the experimental variograms. In cases where the linear model was fit to the empirical variogram, the intercept and slope are reported. The maximum lag distance used was taken as half the total dimension of the field in the direction under consideration. The number of lags was therefore determined by the lag distance and the dimension of each field.

\section{RESULTS}

Late blight, based on disease symptoms and sporulation of $P$. infestans on infected plant tissue, was confirmed by observations on the ground as the cause of plant stress indicated on photographs of each field and sample studied. Disease incidences (pixels with late blight per total pixels) increased over time in the five fields. Final late blight incidences were 27.2, 54.1, 28.7, 52.9, and $70 \%$ in fields I through $\mathrm{V}$, respectively (Table 2 ).

Late blight, as observed in aerial photographs, was present along wheel tracks of the pivot system, near the center pivot and in multiple foci throughout field I in 1993 and in field II on 17 and 24 July 1995 (Fig. 1). In field II on 3 July (first sampling date), incidence of late blight was $0.18 \%$ (Table 2 ) and the disease was observed near wheel lines and the center pivot. Number of disease foci increased between 3 and 17 July and size of foci became enlarged between 17 and 24 July. In field III, disease foci of various sizes were observed throughout the field with one of the larger focus near the pivot center on 17 July (Fig. 1) and 24 July 1995. Many foci had coalesced and late blight had scattered throughout much of field III by 8 August. Two extremely large and numerous smaller foci were observed in field IV on 29 June 1995 (Fig. 1). Disease foci had enlarged and some had coalesced 7 days later. In field V, about 30 distinct disease foci were observed on 23 June 1998. Smaller secondary foci encompassing and between the original foci were observed 6 days later on 29 June (Fig. 2). Foci enlarged by 6 July and most had coalesced and late blight spread to most of the field by 27 July (Fig. 2).

Aggregation of late blight, considering only presence and absence of disease within a pixel, was indicated by runs analysis. Significant z-tests (13) were computed in all four directions during each sampling date in each of the five fields (Table 2). Absolute $\mathrm{z}$-values for runs analysis increased, indicating increasing aggregation, in the four directions tested as disease incidence increased with time in fields II and III. In field IV, absolute Zvalues from runs analysis decreased in two directions, increased in

TABLE 2. Late blight incidence and summary of runs analysis in four directions at one to four sampling dates for five potato fields infected with Phytophthora infestans in the Columbia Basin

\begin{tabular}{|c|c|c|c|c|c|}
\hline \multirow[b]{2}{*}{ Field, cultivar, and date } & \multirow[b]{2}{*}{ Late blight incidence $(\%)^{\mathrm{a}}$} & \multicolumn{4}{|c|}{ Runs $Z$-values ${ }^{\mathrm{b}}$} \\
\hline & & North & Northeast & East & Southeast \\
\hline \multicolumn{6}{|l|}{ Field I, Norkotah Russet } \\
\hline 2 August 1993 & 27.2 & -31.8 & -27.2 & -31.9 & -37.1 \\
\hline \multicolumn{6}{|l|}{ Field II, Shepody } \\
\hline 3 July 1995 & 0.2 & -21.0 & -13.5 & -20.6 & -16.4 \\
\hline 17 July 1995 & 20.9 & -79.8 & -57.7 & -72.9 & -67.7 \\
\hline 24 July 1995 & 54.1 & -83.7 & -57.8 & -98.1 & -76.0 \\
\hline \multicolumn{6}{|l|}{ Field III, Russet Burbank } \\
\hline 17 July 1995 & 4.5 & -18.3 & -16.8 & -16.4 & -13.2 \\
\hline 24 July 1995 & 11.9 & -22.1 & -21.9 & -19.2 & -18.8 \\
\hline 8 August 1995 & 28.7 & -22.6 & -18.6 & -21.1 & -22.2 \\
\hline \multicolumn{6}{|l|}{ Field IV, Shepody } \\
\hline 29 June 1995 & 40.0 & -104.9 & -67.2 & -137.6 & -85.4 \\
\hline 6 July 1995 & 52.9 & -95.6 & -67.7 & -121.8 & -93.4 \\
\hline \multicolumn{6}{|l|}{ Field V, Norkotah Russet } \\
\hline 23 June 1998 & 0.6 & -9.5 & -5.4 & -3.6 & -8.3 \\
\hline 29 June 1998 & 1.6 & -53.2 & -42.2 & -27.1 & -33.7 \\
\hline 6 July 1998 & 16.7 & -93.8 & -75.0 & -52.0 & -69.4 \\
\hline 27 July 1998 & 70.0 & -89.1 & -66.2 & -73.7 & -54.3 \\
\hline
\end{tabular}

a (Pixels with late blight per total pixels) 100.

b Absolute values greater than 2.58 indicate significant aggregation at $P<0.01$. 
one direction, and remained nearly the same in one direction as late blight incidence increased from 40 to $52.9 \%$. In field V, the runs analysis indicated that aggregation increased from the first through the third disease assessment. However, in field V, aggregation decreased in three of four directions and increased in one direction as disease incidence increased from 16.7 to $70 \%$ (Table 2).

Variograms indicated autocorrelation for disease occurrence among pixels in four directions for all fields and almost all dates. The range of influence generally increased as disease incidence increased (Table 3). For field I the range of influence was large in four directions when disease incidence was assessed. The range of influence was about 4 pixels in all four directions examined in field II for the first observation date. The variograms for the 17 July observation date had greater nuggets, sills, and ranges of influence, reflecting greater disease incidence and larger clumps of disease. One week later with late blight incidence at $54.1 \%$, there was evidence of very large clumps of disease with a range of influence greater than 90 pixels in all directions. In field III the range of influence remained fairly stable for 1 week from the first to second sampling periods even though disease incidence increased from 4.5 to $11.9 \%$. The range of influence or size of clumps then increased greatly as late blight incidence increased to $28.7 \%$ for the last observation date on 8 August. The linear variograms for three directions and the large range of influence for the exponential model in the southeast direction for the 29 June observation date in field IV reflects a large-scale spatial trend caused by clumps of diseased and nondiseased areas. The large clumps of disease, and nondisease, dominated the autocorrelation structure even though there were small clumps of disease interspersed in the nondiseased portion of the field. At the second sampling date, 1 week later, the ranges of influence for the four

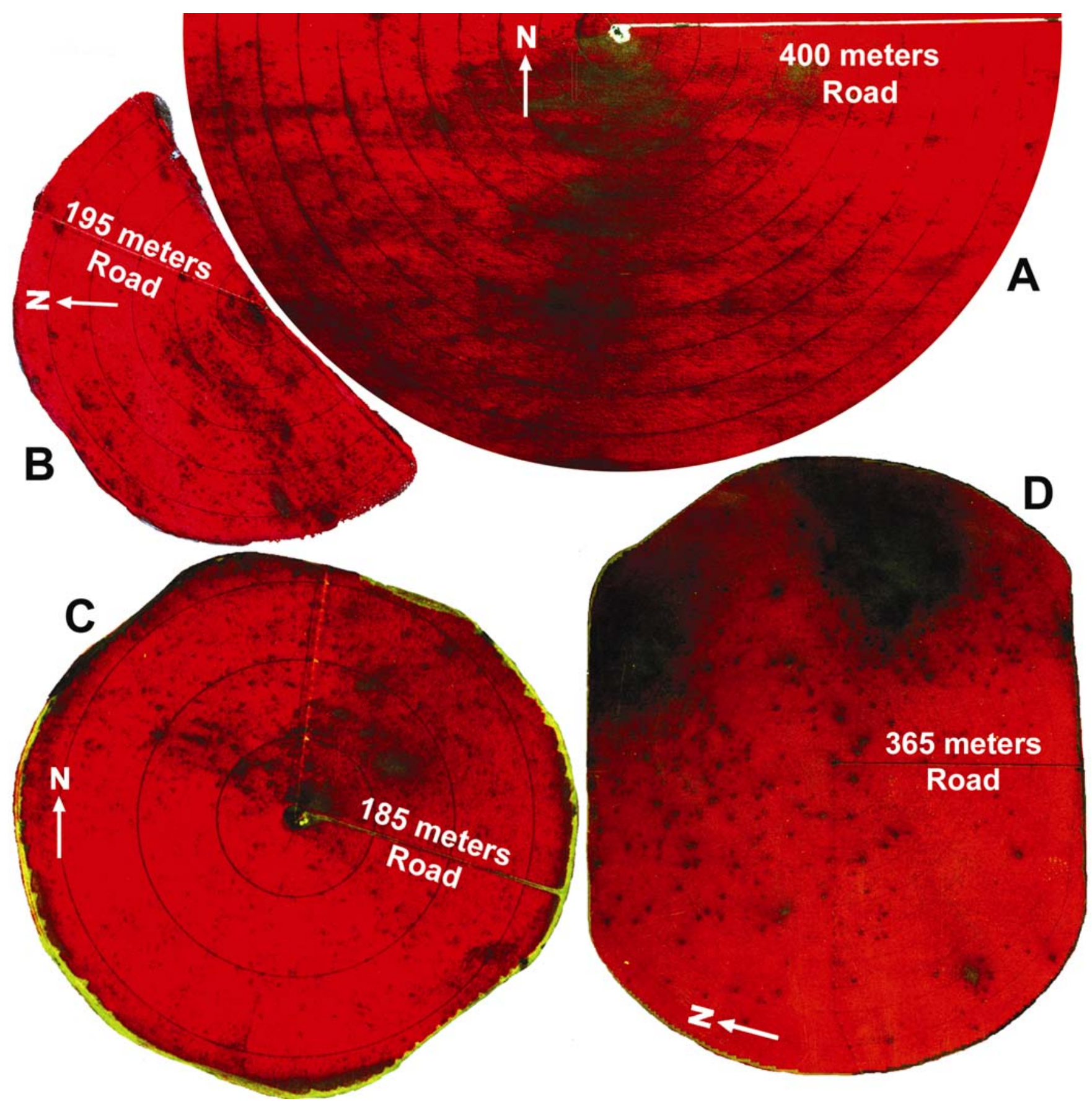

Fig. 1. Color, infrared aerial photograph of A, cv. Norkotah Russet on 2 August 1993 (field I), B, cv. Shepody on 24 July 1995 (field II), C, cv. Russet Burbank on 17 July 1995 (field III), and D, cv. Shepody on 29 June 1995 (field IV). Healthy foliage appears red; diseased appears tan to dark. 
directions remained large, indicating that large clumps of disease persisted as disease incidence increased from 40 to $52.9 \%$. Therefore, as the smaller clumps grew and disease spread, the large clumps of disease and nondiseased pixels no longer dominated the autocorrelation structure. There was little disease present in field $\mathrm{V}$ during the initial assessment. The variogram models in the four directions indicate almost pure nugget effect (i.e., nugget $=$ sill), which suggests that the widely dispersed disease foci were randomly scattered (Fig. 3). The variogram models showed more spatial structure in all directions by the second observation date 6 days later, although the disease incidence remained low (Fig. 4). In the next week, the range of influence increased, reflecting increased disease aggregation as disease incidence increased. The final observation date for field V, 27 July 1998, indicated continued spatial structure with large ranges of influence in all directions. The estimated range of influence decreased from two directions but continued to increase in two directions.

\section{DISCUSSION}

This study shows the potential of using aerial photography to quantitatively analyze patterns of diseased plants over time in relatively large commercial fields. Many previous studies of pathogen or plant disease spatial patterns have been limited to relatively small areas for soilborne pathogens or diseases (43). Disease patterns of hop downy mildew were evaluated in relatively large sections of commercial fields $(16,17)$. However, this was labor intensive and would not always be practical. Spatial studies encompassing large areas are advantageous for airborne pathogens because conclusions are most appropriate at the spatial scale of the study (43).

Spatial variation of late blight in potato fields was aggregated and dynamic as the disease spread within fields during epidemics in the Columbia Basin. An aggregated rather than random or regular pattern was expected for late blight, because after introduction of the disease into a field, new infections are more likely to occur near a previously infected plant (28). The pattern depends on the stage of late blight epidemic and the nature of primary infection. In this study, late blight became more aggregated according to runs analyses as disease incidence increased until the next to last disease assessment in all fields. In field IV there were high levels of disease incidence for both assessment dates and the runs analyses indicated a decrease in aggregation between dates in two directions. Similarly, in field V, small-scale aggregation for the last disease assessment decreased in three directions according to runs analyses.

The approximate range of autocorrelation among late blightinfected plants was found from variograms to generally increase as disease incidence increased over time. Disease clumps were sparse and scattered at low disease incidences and became larger and more clumped as disease incidence increased. Disease clumps were quite large at high incidences of disease. However, disease aggregation decreased in some directions but continued to increase in other directions as disease incidence increased to the highest levels. In contrast, disease aggregation was expected to rapidly decrease as disease incidence increased (34). Few reports with quantitative data have been published concerning degree of disease aggregation relative to disease incidence over time, and additional studies using appropriately sized plots are needed to adequately understand the relationship.

Spatial variation of late blight-infected foliage was distinctive in the pattern of foci in fields II, III, and V, which were assessed early in the progression of the epidemic. Initial foci were generally circular to asymmetrical and clearly defined, and daughter foci were associated with, but separated from parent foci. Daughter foci were often scattered over the field as observed in an earlier study (6). Late blight was also generally more severe in particular locations of a potato circle. The disease frequently occurred
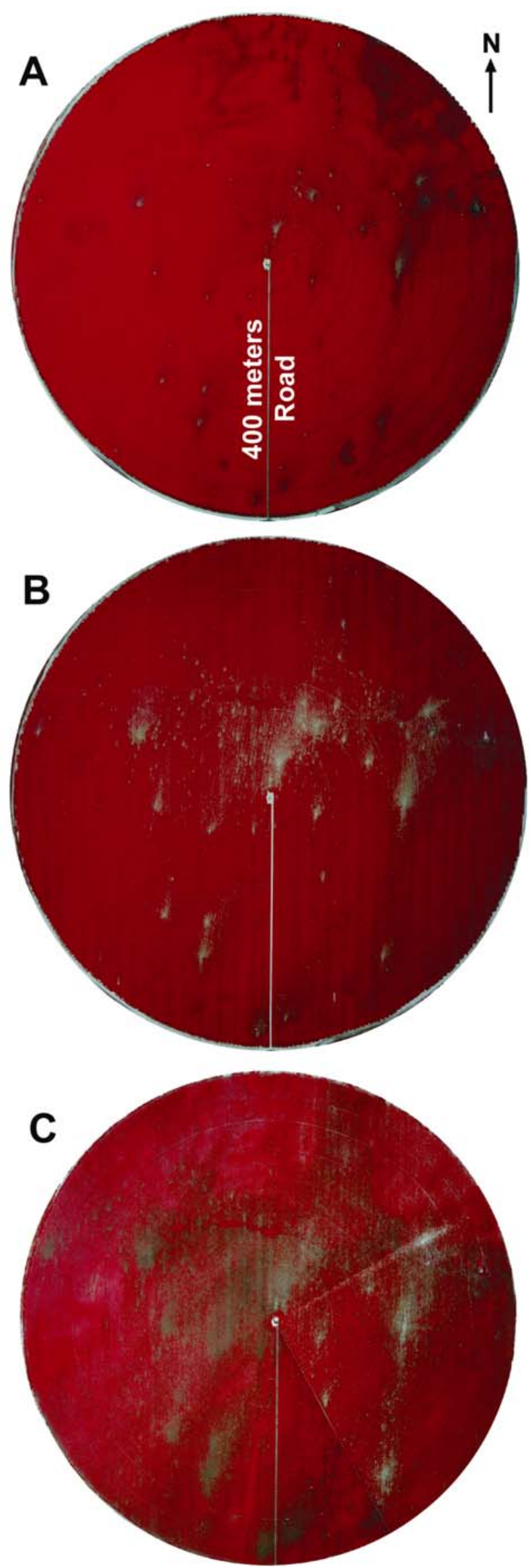

Fig. 2. Color, infrared aerial photograph of cv. Norkotah Russet in 1998 (field V) on A, 29 June, B, 6 July, and C, 27 July. Healthy foliage appears red; diseased appears tan to dark. Dry soil without vegetation (plants previous blighted and killed) appears white to blue. 
TABLE 3. Parameter estimates for exponential (E), linear (L), or spherical (S) models fit to indicator variograms in four directions at one to four sampling dates for five potato fields infected with Phytophthora infestans in the Columbia Basin

\begin{tabular}{|c|c|c|c|c|}
\hline \multirow[b]{2}{*}{ Field, cultivar, and date } & \multicolumn{4}{|c|}{ Estimated parameters $^{\mathrm{a}}$} \\
\hline & North & Northeast & East & Southeast \\
\hline \multicolumn{5}{|l|}{ Field I, Norkotah Russet } \\
\hline 2 August 1993 & $0.08,0.34,>300(\mathrm{E})$ & $0.11,0.09,233(\mathrm{~S})$ & $0.08,0.27,>300(\mathrm{E})$ & $0.08,0.20,204(\mathrm{~S})$ \\
\hline 3 July 1995 & $0.00078,0.00097,3.67(\mathrm{~S})$ & $0.00055,0.0012,4.01(\mathrm{~S})$ & $0.00067,0.0011,3.71(\mathrm{~S})$ & $0.0001,0.0017,2.24(\mathrm{~S})$ \\
\hline 17 July 1995 & $0.05,0.13,31.7(\mathrm{E})$ & $0.08,0.13,119.3(\mathrm{E})$ & $0.08,0.13,76.4(\mathrm{~S})$ & $0.06,0.14,54.6(\mathrm{E})$ \\
\hline 24 July 1995 & $0.108,0.058,90.9(\mathrm{E})$ & $0.099,>1.0,>300(\mathrm{~S})$ & $0.10,0.48,>300(\mathrm{~S})$ & $0.114,0.439,>300(\mathrm{E})$ \\
\hline 24 July 1995 & $0.036,0.051,88.7$ (E) & $0.037,0.041,59.6(\mathrm{~S})$ & $0.040,0.033,46.5(\mathrm{~S})$ & $0.039,0.073,126.9(\mathrm{~S})$ \\
\hline 8 August 1995 & $0.076,0.137,134.9(\mathrm{~S})$ & $0.078,0.236,>300(\mathrm{~S})$ & $0.073,0.262,>300(\mathrm{~S})$ & $0.085,0.170,255.5(\mathrm{~S})$ \\
\hline \multicolumn{5}{|l|}{ Field IV, Shepody } \\
\hline 29 June 1995 & $0.050,0.0005(\mathrm{~L})$ & $0.048,0.0009(\mathrm{~L})$ & $0.038,0.001(\mathrm{~L})$ & $0.052,0.068,>300(\mathrm{E})$ \\
\hline 6 July 1995 & $0.089,0.123,289.3(\mathrm{E})$ & $0.095,0.162,231.8(\mathrm{~S})$ & $0.095,0.150,225.4(\mathrm{~S})$ & $0.082,0.102,184.5(\mathrm{E})$ \\
\hline \multicolumn{5}{|l|}{ Field V, Norkotah Russet } \\
\hline 23 June 1998 & $0.0057,0.00076,24.97(\mathrm{~S})$ & $0.0056,0.0001,31.1(\mathrm{~S})$ & $0.0057,0.0003,13.02(\mathrm{~S})$ & $0.0058,0.00035,34.0(\mathrm{~S})$ \\
\hline
\end{tabular}

${ }^{a}$ Parameters for the exponential (E) model are nugget, sill-nugget, and practical range of influence, respectively. Parameters for the spherical (S) model are nugget, sill-nugget, and range of influence, respectively. Parameters for the linear (L) model are intercept and slope, respectively.

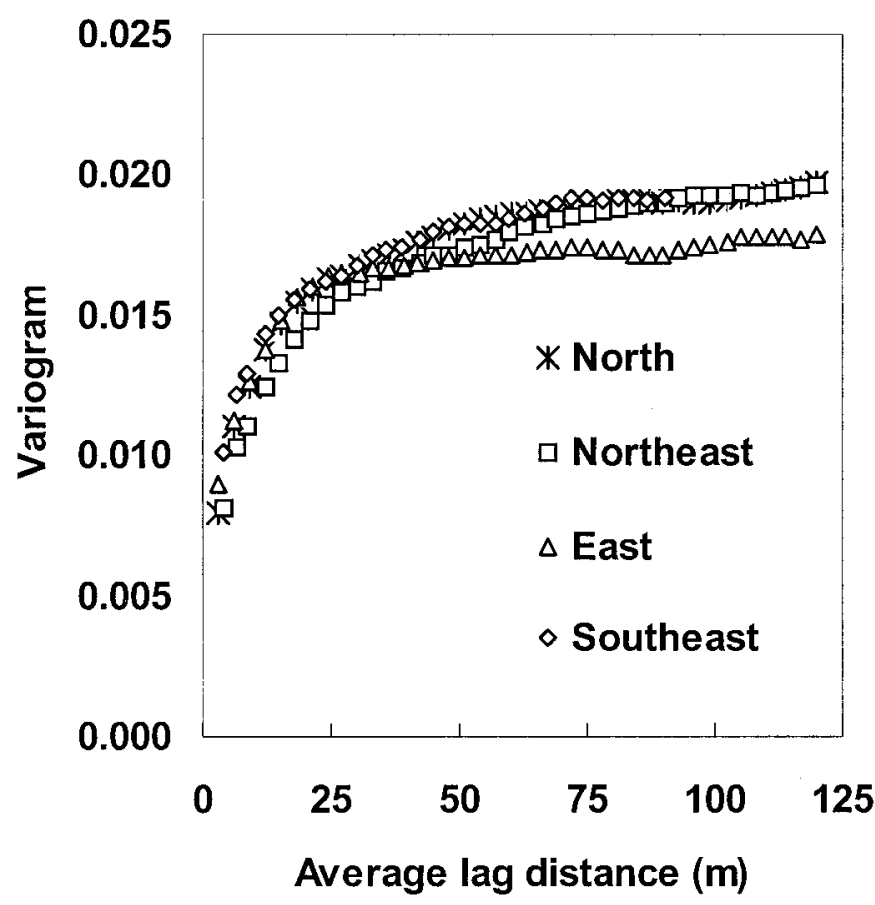

Fig. 3. Variogram as a function of distance (number of pixels) for 29 June 1998 in north, northeast, east, and southeast directions for field V.

earlier and was often more severe near the center of the pivot and along wheel tracks, most likely due to higher humidity and more free water on plant surfaces. More irrigation water is delivered near the pivot center than elsewhere in the circle and pivot wheels compact the soil and water frequently puddles therein. These were the areas most severely infected in the field studied in 1993 when late blight was generally not as severe in the Columbia Basin as in 1995 and $1998(18,19)$.

Spread of late blight in potato fields, as observed from aerial photography, was by foci. Initial foci in a field originate from infected seed or from an external source of airborne sporangia $(14,44)$. Foci enlarged in size, produced daughter foci, coalesced, and the process continued when favored by the environment (41). Disease spreading as foci would account for the increased aggregated patterns as disease incidence increased as found in this study. Disease has been described to spread as a wave $(30,31)$, which implies a continuously moving front. However, the leading edge of the advancing wave has been described as a series of discontinuous jumps, followed by focal formation and secondary spread (30).

The primary source of inoculum for the fields studied is not absolutely known. However, late blight was observed in surrounding fields before finding the disease in studied fields in 1993 and 1995, and primary inoculum for these fields is thought to have originated from an external source to the studied fields. In 1998, late blight is thought to have originated from seed within the studied field (field V). This conclusion is based upon a combination of the following: (i) late blight was first observed in the Hermiston area in the studied field, (ii) late blight was present in the seed field in 1997 that provided seed tubers to plant the Hermiston field, (iii) four other fields planted from this seed tuber source were the first in which late blight was found in the Pasco area in 1998 (Hermiston is $56 \mathrm{~km}$ in distance and against the prevailing winds in relation to Pasco), (iv) late blight was not observed in the Hermiston and Pasco areas or the remainder of the Columbia Basin for at least 12 days after it had been observed in fields from the infected seed source, (v) small distinct foci as seen during the first two disease assessments for field $\mathrm{V}$ would not be expected if sporangia had blown in from another field (42), (vi) refuse tubers were not known to have been exposed above ground after the initiation of planting in either area, and (vii) late blight was not observed on volunteer plants during the epidemic. Oospores in soil probably were not a factor because potatoes had not been grown in the Hermiston field for 3 years. Evidence is circumstantial, but the discussion above suggests that $P$. infestans was associated with seed tubers and is a likely explanation for the early and abrupt appearance of late blight in the five fields in the Columbia Basin in 1998.

Infected seed pieces randomly planted in field $\mathrm{V}$ would account for the random pattern of disease foci first encountered in this field. A random placement of seed tubers at planting is expected (4), provided no sporulation and secondary spread by $P$. infestans in storage or during handling. For one reason, infected tubers from fields producing certified seed tubers are generally at an extremely low incidence and are not likely to be placed in and removed from storage in a nonrandom pattern. Field $\mathrm{V}$ is an example of how inoculum source can influence the spatial pattern of late blight epidemics, especially relatively early in the course of an epidemic. Spread from nearby cull piles has been observed in other studies 


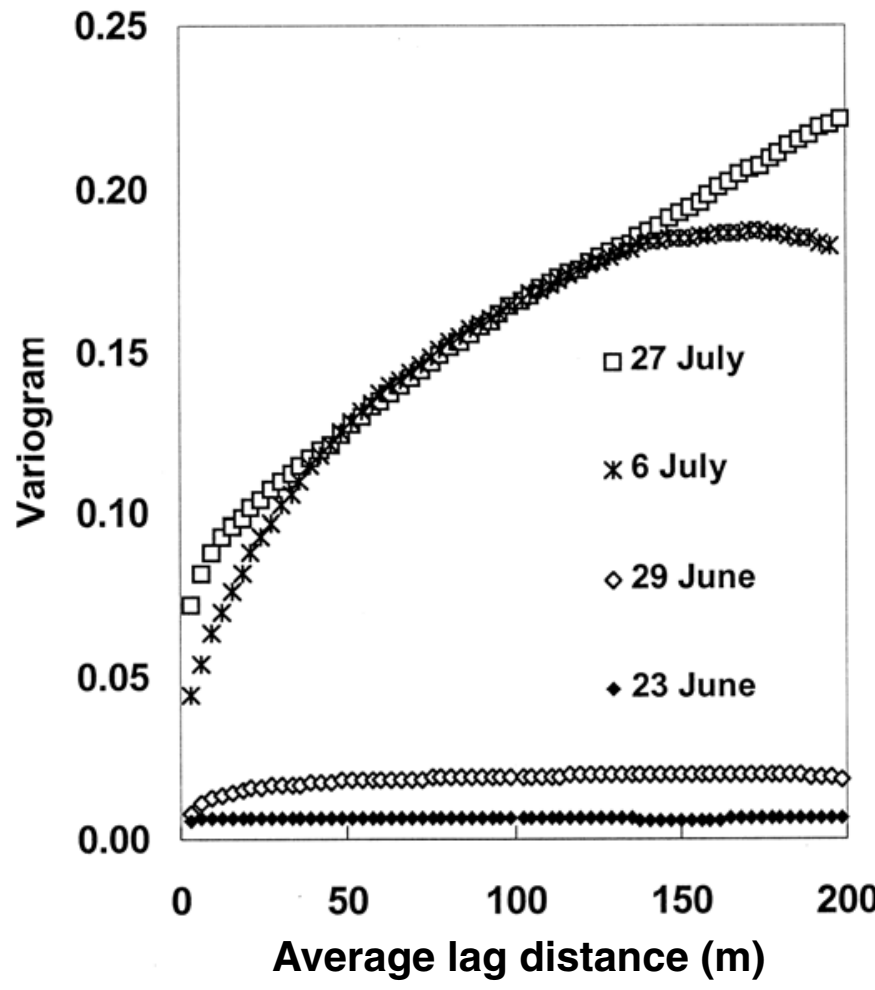

Fig. 4. Variogram as a function of distance (number of pixels) for four dates in the north direction for field $\mathrm{V}$.

as a decreasing disease gradient from the edge of the field near the cull pile with the direction of wind during wet periods $(4,44)$. Aerial photography coupled with spatial pattern analysis of late blight infection is a potential technique to help quantitatively assess the relative importance of seed tubers, cull piles, and volunteer plants as sources of primary inoculum. Such information is essential in developing late blight management strategies and in directing resources for sanitation toward a specific type of inoculum source in a region.

Comparisons among fields, except for initial inoculum sources, were not made in this study because fields were treated differently with fungicides. Four of five fields were treated with fungicides, which may have reduced disease rates (40) and flattened disease gradient curves (31). Host cultivar, weather, irrigation practices, and other factors also alter disease rates and gradients $(31,40,44)$. However, initial disease patterns were not altered by fungicides in fields II, III, and V because fungicides were not applied until after late blight appeared. Later disease patterns are generally influenced by initial patterns. In addition, continued disease development in fields II and III were not significantly altered by fungicides because time intervals between fungicide applications were too wide for control. Disease development in field I was not significantly affected by fungicides because of wide application intervals and the used of copper hydroxide, which does not satisfactorily control late blight in commercial fields in the Columbia Basin. The pattern in field IV was not altered because no fungicides were applied. Disease rates and final disease incidences were moderately high in each field studied, indicating that the fungicides applied did not have a large effect on disease development. Disease patterns observed in this study represent late blight epidemics encountered in the Columbia Basin and are relevant in studying disease spatial pattern under current disease management practices in commercial potato fields.

The importance of this study was to demonstrate the potential of using aerial photography in combination with statistical analyses to quantitatively describe spatial patterns of a plant disease during an epidemic. Aerial photography enabled spatial analyses of relatively large fields. Our results showed that epidemics of potato late blight in the Columbia Basin were characterized by small-scale aggregation of disease as determined by runs analyses even at low levels of disease incidence early in the season. One field (field V) exhibited less initial aggregation (random pattern), perhaps due to a different source of primary inoculum. This pattern could have originated from infected seed tubers randomly scattered throughout the field. In general, the size of disease clumps, as well as the number of disease foci, increased throughout the season. An increase in aggregation was found as late blight epidemics increased in disease incidence for all but the highest levels of disease.

\section{ACKNOWLEDGMENTS}

We thank T. F. Cummings for technical assistance. Plant Pathology Number Series 0324, Department of Plant Pathology, College of Agriculture and Home Economics Research Center, Washington State University, Pullman.

\section{LITERATURE CITED}

1. Bailey, T. C., and Gatrell, A. C. 1995. Interactive Spatial Data Analysis. Longman Scientific and Technical, Essex, England.

2. Blazquez, C. H. 1981. Vegetable crop management with remote sensing. Photogrammetric Engineering Remote Sensing 47:543-547.

3. Blazquez, C. H. 1990. Late blight detection in tomato fields by aerial photography with natural and infrared color film. Plant Dis. 74:589-592.

4. Brenchley, G. H. 1964. Aerial photography of the study of potato blight epidemics. World Rev. Pest Control 3:68-84.

5. Brenchley, G. H. 1968. Aerial photography in agriculture. Outlook Agric. 5:258-265.

6. Brenchley, G. H., and Dadd, C. V. 1962. Potato blight recording by aerial photography. Natl. Agric. Adv. Serv. (Eng.) Q. Rev. 14:21-25.

7. Campbell, C. L., and Noe, J. P. 1985. The spatial analysis of soilborne pathogens and root diseases. Annu. Rev. Phytopathol. 23:129-148.

8. Danos, E., Berger, R. D., and Stall, R. E. 1984. Temporal and spatial spread of citrus canker within groves. Phytopathology 74:904-908.

9. Drenth, A., Janssen, E. M., and Govers, F. 1995. Formation and survival of oospores of Phytophthora infestans under natural conditions. Plant Pathol. 44:86-94.

10. Everitt, J. H., Escobar, D. E., Appel, D. N., Riggs, W. G., and Davis, M. R. 1999. Using airborne digital imagery for detecting oak wilt disease. Plant Dis. 83:502-505.

11. Gavino, P. D., Smart, C. D., Sandrock, R. W., Miller, J. S., Hamm, P. B., Lee, T. Y., Davis, R. M., and Fry, W. E. 2000. Implications of sexual reproduction for Phytophthora infestans in the United States: Generation of an aggressive lineage. Plant Dis. 84:731-735.

12. Gibbons, J. D. 1976. Nonparametric Methods for Quantitative Analysis. Holt, Reinhart, and Winston, New York.

13. Goovaerts, P. 1997. Geostatistics for Natural Resources Evaluation. Oxford University Press, New York.

14. Hirst, J. M., and Stedman, O. J. 1960. The epidemiology of Phytophthora infestans. II. The source of inoculum. Ann. Appl. Biol. 48:489-517.

15. Inglis, D. A., Johnson, D. A., Legard, D. E., Fry, W. E., and Hamm, P. B. 1996. Relative resistance of potato clones in response to new and old populations of Phytophthora infestans. Plant Dis. 80:575-678.

16. Johnson, D. A., Alldredge, J. R., Allen, J. R., and Allwine, R. 1991. Spatial pattern of downy mildew in hop yards during severe and mild disease epidemics. Phytopathology 81:1369-1374.

17. Johnson, D. A., Alldredge, J. R., and Fisher, R. 1988. Spatial pattern of downy mildew in hop yards. Phytopathology 78:1389-1395.

18. Johnson, D. A., Alldredge, J. R., and Hamm, P. B. 1988. Expansion of potato late blight forecasting models for the Columbia Basin of Washington and Oregon. Plant Dis. 82:642-645.

19. Johnson, D. A., Alldredge, J. R., and Vakoch, D. L. 1996. Potato late blight forecasting models for the semiarid environment of south-central Washington. Phytopathology 86:480-484.

20. Johnson, D. A., Cummings, T. F., and Hamm, P. B. 2000. Cost of fungicides used to manage potato late blight in the Columbia Basin: 1996 to 1998. Plant Dis. 84:399-402.

21. Johnson, D. A., Cummings, T. F., Hamm, P. B., Rowe, R. C., Miller, J. S., Thornton, R. E., Pelter, G. Q., and Sorensen, E. J. 1997. Potato late blight in the Columbia Basin: An economic analysis of the 1995 epidemic. Plant Dis. 81:103-106.

22. Journel, A. G., and Huijbregts, C. H. 1978. Mining Geostatistics. Academic Press, New York. 
23. Madden, L. V., Louie, R., Abt, J. J., and Knoke, J. K. 1982. Evaluation of tests for randomness of infected plants. Phytopathology 72:195-198.

24. Manzer, F. E., and Cooper, G. R. 1967. Aerial photographic methods of potato disease detection. Maine Agric. Exp. Stn. Bull. 646.

25. Manzer, F. E., and Cooper, G. R. 1982. Use of portable videotaping for aerial infrared detection of potato diseases. Plant Dis. 66:665-667.

26. Marshall, K. D., and Stevenson, W. R. 1996. Transmission of Phytophthora infestans from infected seed potato tubers to developing sprouts. (Abstr.) Am. Potato J. 73:370-371.

27. Miller, J. S., Hamm, P. B., and Johnson, D. A. 1997. Characterization of the Phytophthora infestans population in the Columbia Basin of Oregon and Washington from 1992 to 1995. Phytopathology 87:656-660.

28. Miller, J. S., and Johnson, D. A. 2000. Competitive fitness of Phytophthora infestans isolates under semiarid field conditions. Phytopathology 90:220-227.

29. Miller, J. S., Johnson, D. A., and Hamm, P. B. 1998. Aggressiveness of isolates of Phytophthora infestans from the Columbia Basin of Washington and Oregon. Phytopathology 88:190-197.

30. Minoque, K. P., and Fry, W. E. 1983. Models for the spread of plant disease: Model description. Phytopathology 73:1168-1173.

31. Minogue, K. P., and Fry, W. E. 1983. Models for the spread of disease: Some experimental results. Phytopathology 73:1173-1176.

32. Nilsson, H. E. 1995. Remote sensing and image analysis in plant pathology. Can. J. Plant Pathol. 17:154-166.

33. Pielou, E. C. 1974. Population and Community Ecology: Principles and Methods. Gordon and Breach Science Publishers, New York.

34. Ristanio, J. B., and Gumpertz, M. L. 2001. New frontiers in the study of dispersal and spatial analysis of epidemics caused by species in the genus
Phytophthora. Annu. Rev. Phytopathol. 38:541-576.

35. Ristaino, J. B., Larkin, R. P., and Campbell, C. L. 1993. Spatial and temporal dynamics of Phytophthora epidemics in commercial bell pepper fields. Phytopathology 83:1312-1320.

36. Rouse, D. I., MacKenzie, D. R., Nelson, R. R., and Elliot, V. J. 1981. Distribution of wheat powdery mildew incidence in field plots and relationship to disease severity. Phytopathology 71:1015-1020.

37. Stevenson, W. R. 1993. Management of early blight and late blight. Pages 141-147 in: Potato Health Management. R. C. Rowe, ed. The American Phytopathological Society, St. Paul, MN.

38. Toler, T. W., Smith, B. D., and Harlan, J. C. 1981. Use of aerial color infrared photography to evaluate crop disease. Plant Dis. 65:24-31.

39. Turechek, W. W., and Madden, L. V. 1999. Spatial pattern analysis of strawberry leaf blight in perennial production systems. Phytopathology 89:421-433.

40. Van der Plank, J. E. 1963. Plant Diseases: Epidemics and Control. Academic Press, New York.

41. Van der Plank, J. E. 1975. Principles of Plant Infection. Academic Press, New York.

42. Wu, B. M., van Bruggen, A. H. C., Subbarao, K. V., and Pennings, G. G. H. 2001. Spatial analysis of lettuce downy mildew using geostatistics and geographic information systems. Phytopathology 91:134-142.

43. Xiao, C. L., Hao, J. J., and Subbarao, K. V. 1997. Spatial patterns of microsclerotia of Verticillium dahliae in soil and Verticillium wilt of cauliflower. Phytopathology 87:325-331.

44. Zwankhuizen, M. J., Govers, R., and Zadoks, J. C. 1998. Development of potato late blight epidemics: Disease foci, disease gradients, and infection sources. Phytopathology 88:754-763. 